\title{
Analysis on Development Status and Countermeasures of Productive Service Industry in Jiangsu under New Normal
}

\author{
Dan Lu \\ College of Jincheng \\ Nanjing University of Aeronautics and Astronautics \\ Nanjing, China 211156
}

\begin{abstract}
Under New Normal, productive output in Jiangsu increases continuously, but the overall development level is low; the efforts made to create employment is not enough; regional development is unbalanced; the agglomeration degree of productive service industry is not high. It is necessary to rely on the Yangtze River delta economic circle, promote structure upgrading of productive service industry; devote greater efforts to investment in human capital, introduce and cultivate innovative talents; build central city, drive development of productive service industry in central and northern Jiangsu; carry out scientific layout, cultivate diversified characteristic cluster of productive service industry and improve competitiveness of productive service industry in Jiangsu.
\end{abstract}

Keywords-new normal; productive service industry; countermeasures

\section{INTRODUCTION}

Under New Normal, our country has begun to develop from "industrial-based economy" to "service-oriented economy". Modern service industry has become assistor to adjust industrial structure and promote industry upgrading. As pacesetter of national economy, Jiangsu shall focus on productive service industry to accelerate the development of modern service industry. In 2015, the proportions of three times of industrial added value in Jiangsu was 5.7 to 45.7 to 48.6 and realized " 321 " significant change of industrial structure. However, compared with some big provinces with service industry, it still lags behind. The development level of service industry remains to be improved further.

As burgeoning modern service industry, productive service industry runs through various links of upstream, midstream and downstream in production of enterprise, has advantages such as high knowledge-intensive degree, less resource consumption and high added value of output and plays a vital role in promoting industrial adjustment and upgrade and improving production efficiency. Productive service industry depends on manufacturing enterprise to exist, including transportation, warehousing and postal industry, financial industry, real estate industry, leasing and commercial service, scientific research and technology service, information transmission, software and information technology service industry. [1]

\section{ANALYSIS ON DEVElopment Status of Productive SERVICE INDUSTRY IN JIANGSU}

\section{A. Output Value of Productive Service Industry Increases Continuously, But the Overall Development Level Is Low}

Service industry plays an increasingly important role in economic development of Jiangsu. In 2015, the proportion occupied by value added of service industry in Jiangsu province in GDP reaches $48.6 \%$, exceeding that of the secondary industry for the first time. The adjustment of industrial structure realizes significant change from " 231 " to "321". But compared with Shanghai, it still needs improvement. The proportion occupied by value added of the tertiary industry in Shanghai in its GDP in Shanghai at the same period reaches $67.8 \%$. [2] Looking from interior of service industry, in recent years, the output value of productive service industry increases year by year, but the growing rate is not large. (See "Table I") "Table II" shows that the growth rate of leasing and commercial service industry is the most rapid during 2008 to 2014. The proportion occupied rises from $9.10 \%$ to $15.62 \%$. It is followed by financial industry. The proportion occupied rises from $23.39 \%$ to $29.87 \%$. The proportion occupied by transportation, warehousing and postal industry decreases obviously. The development of productive service industry in Jiangsu depends on financial industry. In 2014, the total proportion occupied by real estate, transportation, warehousing and postal industries in productive service industry reached up to $68.8 \%$, but the proportion occupied by high-end science and technology service industry in service industry was only $5.59 \%$.

\section{B. Efforts Made to Create Employment in Productive Service Industry Are Inadequate}

The role played by productive service industry in absorbing labor force is not prominent. Proportion occupied by employees has the tendency to decline in recent years, and it is still very low on the whole. Besides, relatively large gap also exists in internal industries of productive service industry. The number of employees in transportation, warehousing and postal industry is the largest. Employees in these industries make the biggest contributions. According to "Table III" and 
decrease of proportion of output value in this industry, it shows that the labor intensive degree of this industry becomes increasingly high; in recent years, information transmission, software and information technology service industry develops very fast. Especially in 2013, the number of employees absorbed by it increases greatly.

TABLE I. GDP of Sub-SEctors of Productive SERVICE INDUSTRY IN JiANGSU (UNit: 0.1 BilLiON YUAN)

\begin{tabular}{|c|c|c|c|c|c|c|c|}
\hline & 2008 & 2009 & 2010 & 2011 & 2012 & 2013 & 2014 \\
\hline Financial industry & 1298 & 1597 & 2106 & 2600 & 3137 & 3959 & 4724 \\
\hline Real estate industry & 1626 & 2025 & 2601 & 2748 & 2993 & 3308 & 3564 \\
\hline $\begin{array}{l}\text { Transportation, warehousing and postal } \\
\text { industry }\end{array}$ & 1346 & 1423 & 1768 & 2128 & 2352 & 2425 & 2591 \\
\hline $\begin{array}{l}\text { Information transmission, software and } \\
\text { information technology service industry }\end{array}$ & 504 & 527 & 605 & 911 & 1104 & 1361 & 1580 \\
\hline Leasing and commercial service industry & 505 & 556 & 868 & 1191 & 1415 & 2034 & 2470 \\
\hline $\begin{array}{l}\text { Scientific research and technical service } \\
\text { industry }\end{array}$ & 272 & 309 & 365 & 496 & 613 & 774 & 885 \\
\hline Total value of productive service industry & 5551.05 & 6436.6994 & 8313.96 & 10074.5 & 11613.29 & 13861.72 & 15812.88 \\
\hline $\begin{array}{l}\text { Proportion occupied by productive } \\
\text { service industry in service industry } \%\end{array}$ & $46.69 \%$ & $47.23 \%$ & $48.53 \%$ & $48.34 \%$ & $49.38 \%$ & $50.97 \%$ & $51.68 \%$ \\
\hline
\end{tabular}

Source: Data of Jiangsu Statistical Yearbook every year

TABLE II. Changes OF Proportion OCCUPIED By SUB-SECTORS OF ProduCtive SERVICE INDUSTRY IN JiANGSU IN 2008 AND 2014

\begin{tabular}{|l|l|l|l|l|c|}
\hline $\begin{array}{c}\text { Changes of } \\
\text { proportion occupied } \\
\text { by sub-sectors of } \\
\text { productive service } \\
\text { industry in Jiangsu } \\
\text { in 2008 and 2014 }\end{array}$ & $\begin{array}{c}\text { Financial } \\
\text { industry }\end{array}$ & $\begin{array}{c}\text { Real estate } \\
\text { industry } \\
\text { warehousing and } \\
\text { postal industry }\end{array}$ & $\begin{array}{c}\text { Transportation, } \\
\begin{array}{c}\text { Information } \\
\text { transmission, } \\
\text { software and } \\
\text { information } \\
\text { technology service } \\
\text { industry }\end{array}\end{array}$ & $\begin{array}{c}\text { Leasing and } \\
\text { commercial } \\
\text { service industry }\end{array}$ & $\begin{array}{c}\text { Scientific } \\
\text { research and } \\
\text { technical } \\
\text { service } \\
\text { industry }\end{array}$ \\
\hline 2008 & $23.39 \%$ & $29.29 \%$ & $24.25 \%$ & $9.07 \%$ & $9.10 \%$ \\
\hline 2014 & $29.87 \%$ & $22.54 \%$ & $16.39 \%$ & $9.99 \%$ & $15.62 \%$ \\
\hline
\end{tabular}

Source: Data of Jiangsu Statistical Yearbook in 2008 and 2014

TABLE III. SITUATION OF URBAN EMPLOYED PERSONS IN PRODUCTIVE SERVICE INDUSTRY IN JIANGSU (UNIT: TEN THOUSAND)

\begin{tabular}{|c|c|c|c|c|c|c|}
\hline & 2008 & 2009 & 2010 & 2012 & 2013 & 2014 \\
\hline Financial industry & 25.05 & 26.62 & 26.9 & 29.36 & 30.79 & 33.32 \\
\hline Real estate industry & 5.96 & 6.49 & 7.31 & 8.23 & 21.19 & 22.14 \\
\hline $\begin{array}{l}\text { Transportation, warehousing and } \\
\text { postal industry }\end{array}$ & 31.97 & 30.7 & 31.23 & 30.61 & 48.41 & 49.78 \\
\hline $\begin{array}{l}\text { Information transmission, software } \\
\text { and information technology service } \\
\text { industry }\end{array}$ & 7.27 & 7.33 & 8.65 & 10.79 & 30.46 & 29.04 \\
\hline $\begin{array}{l}\text { Leasing and commercial service } \\
\text { industry }\end{array}$ & 11.01 & 11.46 & 12.04 & 12.32 & 31.86 & 31.23 \\
\hline $\begin{array}{l}\text { Scientific research and technical } \\
\text { service industry }\end{array}$ & 9.39 & 9.85 & 10.86 & 12.78 & 19.25 & 21.51 \\
\hline $\begin{array}{l}\text { Number of employees in productive } \\
\text { service industry }\end{array}$ & 90.65 & 92.45 & 96.99 & 104.09 & 181.96 & 187.02 \\
\hline $\begin{array}{l}\text { Proportion occupied in total number of } \\
\text { employees in urban units }\end{array}$ & $12.81 \%$ & $12.82 \%$ & $12.70 \%$ & $12.53 \%$ & $12.10 \%$ & $11.67 \%$ \\
\hline
\end{tabular}

Source: Data of Jiangsu Statistical Yearbook every year

\section{Regional Development Is Unbalanced}

Unbalanced regional economic development is prominent problem is economic development of Jiangsu. It is also reflected on productive service industry. "Table IV" shows that the proportion occupied by tertiary industry in GDP in recent years in southern, central and northern Jiangsu. Meanwhile, southern Jiangsu has greater advantage. The proportion 
occupied by central and northern Jiangsu is relatively low. And the gap continues to increase. Looking from the amount of investment, in 2014, the amounts of investment of the tertiary industry in southern, central and northern Jiangsu are 1,247.8 billion yuan, 387.4 billion yuan and 463 billion yuan. Regional difference is relatively obvious.

TABLE IV. PROPORTION OCCUPIED By AdDED VALUE OF THE TERTIARY INDUSTRY IN GDP $(\%)$

\begin{tabular}{|l|l|l|l|l|l|l|l|}
\hline \multicolumn{1}{|c|}{ Area } & $\mathbf{2 0 0 8}$ & $\mathbf{2 0 0 9}$ & $\mathbf{2 0 1 0}$ & $\mathbf{2 0 1 1}$ & $\mathbf{2 0 1 2}$ & $\mathbf{2 0 1 3}$ & $\mathbf{2 0 1 4}$ \\
\hline $\begin{array}{l}\text { Southern } \\
\text { Jiangsu }\end{array}$ & 40.9 & 42.1 & 43.7 & 44.8 & 46.2 & 48.0 & 50.0 \\
\hline $\begin{array}{l}\text { Central } \\
\text { Jiangsu }\end{array}$ & 35.2 & 35.7 & 37.5 & 38.6 & 40.0 & 41.9 & 43.6 \\
\hline $\begin{array}{l}\text { Northern } \\
\text { Jiangsu }\end{array}$ & 35.7 & 36.1 & 38.6 & 39.2 & 39.8 & 41.5 & 42.6 \\
\hline
\end{tabular}

Source: Data of Jiangsu Statistical Yearbook every year

\section{The Agglomeration Degree of Productive Service Industry Is Not High}

The average agglomeration rate of productive service industry in Jiangsu is among the front rank across the country. But great gap still exists between Beijing, Shanghai and it. Beijing and Shanghai have formed relatively mature modern service industry cluster. Six major high-end industrial functional areas in Beijing such as Zhongguancun Science and Technology Park, Financial Street, economic and technological development zone, central business district, airport economic zone and Olympic Central District gather more than $50 \%$ of productive service industry of Beijing. Shanghai has built 38 functional zones of productive service industry. As carrier to connect upstream and downstream industrial chain, functional zones of productive service industry have become new engine to drive development of industry in the future in Shanghai. At present, the construction of productive service area in Jiangsu lags far behind Beijing and Shanghai no matter on development scale or agglomeration effects produced. The lack of agglomeration effect of productive service industry has restricted development of modern service industry in Jiangsu. [3]

\section{FACTORS THAT RESTRICT DEVELOPMENT LEVEL OF PRODUCTIVE SERVICE INDUSTRY IN JIANGSU}

\section{A. The form of Development of Service Industry Is Single}

Because at present, manufacturing industry in Jiangsu province is in middle and low end of industrial chain, it leads to the situation that the demands of manufacturing industry for productive service industry mainly focus on traditional service industries such as transportation, warehousing, wholesale end retail trade, but it has relatively low requirements for technology-intensive productive service industry such as finance and insurance industry, information technology and ecommerce and the demand forms are single. In addition, although the development of traditional service industry in Jiangsu province is relatively mature, circumstances such as single service type, weak functions, not high quality of service and nonstandard service market exist universally, so the level of competition of service industry in our province is relatively low and cannot adapts to upgrading of industrial structure.

\section{B. The Structure of Service Industry Is Unreasonable}

At present, Jiangsu mainly focuses on traditional service industry, with relatively antiquated infrastructure and low technological content and additional value. Although Jiangsu province has established some relatively successful industrial parks, the labor intensive industry-based economy dominates. It depends on cost advantage and price to compete, with inadequate innovation ability of products, insufficient efforts made to research and develop new products, relatively backward scientific and technological progress and industrial upgrading. In industrial chain, it mainly produces physical products. The service industry is still traditional. The level, additional value and technological content are relatively low. The proportion occupied by modern productive service industries with information technology as the core such as finance, e-commerce and modern logistics is relatively small. It leads to the situation that the internal structure of service industry is unreasonable and the level is not high. It leads to unreasonable internal structure of service industry and low level in our province, which seriously restrict the development of productive service industry.

\section{Regional Internal Resources Are Dispersive}

At present, the layout of regional service industry in Jiangsu is relatively dispersive. Development of permeability hasn't been formed inside the region, so it is impossible to form industrial strength and scale effect. It is mainly because industrial cluster of manufacturing industry and advantages of agglomeration effect do not appear clearly. The resources faced by service industry on the basis of it are relatively dispersive, with less type and agglomeration degree. At the meantime, problems such as low-level redundant development, wasting of resources and internal competition appear in development of the existing productive service industry. It leads to the situation that the industrial strength is not obvious and economic benefit does not form scale.

\section{The degree of Opening of Market in Service Industry Is Relatively Low}

After our country enters the WTO, international industry and international capital are speeding up to flow to range of services in our country. Jiangsu province is an economyprosperous province of our country. At present, the degree of opening of market in service industry is low, with many monopolistic operational projects such as railway, civil aviation, telecommunications and finance. It has monopoly in different extent, lacks competitiveness and causes decrease of efficiency; the degree to use foreign capital is low. Outsourcing projects mainly focus on production of products. Besides, there are few outsourcing services and it does not cover a wide range. The proportion occupied by modern productive service industry closely related to manufacturing industry is lower. 


\section{COUNTERMEASURES TO IMPROVE DEVELOPMENT LEVEL OF PRODUCTIVE SERVICE IN JIANGSU}

\section{A. Depend on the Yangtze River Delta Economic Circle and Promote Structure Upgrading of Productive Service Industry}

In 2014, the GDP gross of sixteen cities in core area of Yangtze River Delta breaks through ten trillion yuan, with average growth rate of $9.0 \%$. It far surpasses average value of our nation. Shanghai is in a central position of the Yangtze River Delta Economic Circle. The level of productive service industry is considerably higher than that of Jiangsu. Jiangsu shall make the best of its economic radiation and demonstration effect and vigorously excavate depth and width of productive service industry, take advantage of resources and talents in Yangtze River Delta and speed up scale and speed of development of productive service industry in Jiangsu. Unceasingly expand industrial chain of productive service industry, depend on means such as "internet plus" to speed up transformation and upgrading of traditional service industry, promote optimization of internal structure of productive service industry; fully exert good basis of manufacturing industry in Jiangsu, strengthen industry integration, intensify coordination and interaction between productive service industry and manufacturing industry, create more intermediate demand and drive development of productive service industry. [4]

Intensify Investment In Human Capital, Introduce And Cultivate Innovative Talents.

Professional talents with multiple levels and reasonable structure are the technical support of sound development of productive service industry. Therefore, it is necessary to vigorously introduce and absorb high-tech and high quality comprehensive professional skilled talents, and introduce a series of preferential policies, perfect multi-layered education and training system, establish talents training mode of integration of industry, university, research and business, quicken the pace to train innovative, applied and compound talents; encourage innovations, improve science and technology research and development ability and technological innovative ability of productive service industry, stimulate scientific and technical personnel to carry out innovation and entrepreneurship, create good environment for transfer and transformation of scientific and technological achievements, devote greater efforts to supporting research and development institutions, institutions of higher learning and personnel with prominent transformation performance of scientific and technological achievements and perfect transformation mechanism of scientific and technological achievements. [5]

\section{B. Build Central City and Promote Development of Productive Service Industry in Northern and Central Jiangsu}

The research shows that the effective sphere of influence of productive service industry agglomeration on technology spillover effect of economic growth is within one hundred kilometers. Northern, central and southern Jiangsu shall drive construction of central cities such as Xuzhou and Lianyungang.
Lianyungang is an important mode city of new Eurasian Continental Bridge economic cooperation corridor of national "the Belt and Road" (B\&R). Speed up construction of international logistics park of Shanghai Cooperation Organization and China-Kazakhstan logistics cooperation base, give full play to resource superiority of the port, perfect infrastructure construction, improve service level and drive implementation of national "B\&R" strategy. Meanwhile, it will make Lianyungang reach a new level on construction of central city of international seaport, and radiate and boost development of surrounding areas and cities. As representative city in central Jiangsu, through construction of regional international shipping logistics center, financial center, modern business trade center, information production and switching center as well as science and technology innovation center, Nantong promotes size and quality of economy of productive service industry, form service economy pattern dominated by productive service industry, drive structure upgrading of service industry, in order to construct economic center in northern Yangtze River Delta.

\section{With Scientific Layout, Cultivate Diversified Characteristic Cluster of Productive Service Industry}

Technology spillover effect of diversified agglomeration of productive service is obvious in eastern developed regions of our country. Therefore, Jiangsu province needs to ensure professional scale of productive service industry and pay more attention to its diversified development, as well as meet demands of diversified industrial development through establishing cluster district of productive service industry with diversified forms and cooperative development of industries. Speed up upgrading of function of cluster district in productive service industry, focus on the implementation of "demonstration project for improvement of one hundred regions in productive service industry", further perfect supporting service function and strengthen absorption capacity of elements, industrial supporting ability and radiating driving ability, cultivate and form one hundred cluster districts of productive service industry with relatively strong influence and demonstration effect in our country. Stand on regional industrial base and endowment advantage, choose some subdivided trade structures to support, and cultivate characteristic cluster districts of productive service industry. Establish radiation network of three-dimensional transportation, create good transportation conditions for development of productive service industry through convenient and efficient transportation system. Meanwhile, it is necessary strengthen construction of public service platform, pay attention to progressing the construction of electronic information service platform, e-commerce platform, science and technology innovation service platform, product design and quality testing platform as well as financial service platform and form a batch of key enterprises and demonstration projects.

\section{REFERENCES}

[1] Han Feng, Wang Zhuozhuo, Yang Ligao. Productive Service Industry Agglomeration, Space Technology Spillover Effect and Economic Growth [J], Industrial Economics Research, 2014.2; 1-10. 
[2] Sheng Long, Lu Genyao. Research on Productive Service Industry Agglomeration in China and Its Influence Factor-Analysis on Industry and Regional Level [J], Nankai Economic Studies, 2013.5;115-129.

[3] Yang Yong. Research on Competitiveness of Productive Service Industry in Shanghai City [D], Shanghai Normal University, 2011; 5355.

[4] Yang Renfa. Development of Productive Service Industry, Competitiveness of Manufacturing Industry and Industry Integration [D], Nankai University, 2013;85-88.

[5] Luo Haiping. Research on Productive Service Industry Agglomeration of Optimized Development Area-Take Yangtze River Delta Region as an Example [D], Wuhan University of Technology, 2013; 103-108. 